\title{
Hydrogen Cyanide Content of Manihort Utilissima, Colocasia Esculenta, Dioscorea Bulbifera and Dioscorea Domentorum Tubers Found in Benue State
}

\author{
B.A Anhwange \\ Department of chemistry, Benue State University \\ P.M.B 102119 Makurdi \\ banhwange@yahoo.com \\ K. Asemave, B.A. Ikyenge \& D.A Oklo \\ Department of chemistry, Benue State University \\ P.M.B 102119 Makurdi \\ Accepted: April 30, $2011 \quad$ Published: December 1, 2011 \\ URL: http://dx.doi.org/10.5539/ijc.v3n4p69
}

Received: April 12, 2011

doi:10.5539/ijc.v3n4p69

\begin{abstract}
The hydrogen cyanide contents of Manihort utilissima (Cassava), Colocasia esculenta (Coco yam), Dioscorea bulbifera (Aerial yam) and Dioscorea domentorum (Trifoliate yam) Tubers found in Benue State were determined in their fresh and dried forms. The amount of hydrogen cyanide found in the fresh state was 304.60 $\mathrm{mg} \cdot 100 \mathrm{~g}^{-1}, 34.10 \mathrm{mg} \cdot 100 \mathrm{~g}^{-1}, 49.70 \mathrm{mg} \cdot 100 \mathrm{~g}^{-1}$ and $79.40 \mathrm{mg} \cdot 100 \mathrm{~g}^{-1}$ for Manihort utilissima, Colocasia esculenta, Dioscorea bulbifera and Dioscorea domementeroum respectively; while the amount observed in the dry form was $249.50 \mathrm{mg} \cdot 100 \mathrm{~g}^{-1}, 17.30 \mathrm{mg} \cdot 100 \mathrm{~g}^{-1}, 32.50 \mathrm{mg} \cdot 1200 \mathrm{~g}^{-1}$ and $55.10 \mathrm{mg} \cdot 100 \mathrm{~g}^{-1}$ for Manihort utilissima, Colocasia esculenta, Dioscorea bulbifera and Dioscorea domementeroum respectively. Higher hydrogen cyanide contents were observed in the fresh samples than the dried samples. Manihort utilissima was found to have the highest values both in the fresh and the dried forms. Statistical analysis of the mean values of hydrogen cyanide content of the tubers indicates a significant difference between the fresh and the dried forms of the tubers. The study revealed that tubers of these plants have relatively high content of hydrogen cyanide content.
\end{abstract}

Keywords: Hydrogen cyanide, Analysis, Manihort utilissima, Colocasia esculenta, Dioscorea bulbifera and Dioscorea domentorum

\section{Introduction}

Hydrogen cyanide is a colourless liquid or gas with a faint, bitter almond odour. It has a molecular formula HCN. It is readily soluble in water. Its solution in water is known as hydrocyanic acid or prussic acid. Its other name is formonitrile. Salts of $\mathrm{HCN}$ are called cyanides. Formonitrile is a poisonous substance; as such it is often regarded as an anti-nutritional factor (ATSDTR, 1993).

According to Kamalu (1995), cassava root, a dietary staple in many tropical regions contains cyanogenic glycosides, such as linamarin, which release cyanide $\left(\mathrm{CN}^{-}\right)$when metabolised endogenously. Jantz et al. (1997), reported that, people eating food that contain low level of cyanide for a long time develop damage to the central nervous system (CNS) and thyroid gland. To buttress this, Kamalu (1995) stressed that long time ingestion of food containing cyanide can lead to deafness, vision problems, and loss of muscle coordination. The effect of this on thyroid gland is cretinism (retarded physical and mental growth in children), or enlargement and over activity of the gland. Other effects of cyanide include.

Pancreatic diabetes, vitamin $\mathrm{B}_{12}$ deficiency, and decrease in iodine uptake (Makkar et al., 1998). Liver inflammation and haemorrhage, kidney, adrenal, myocardial and testicular lesion have been observed in dogs that consumed cassava containing low amounts of cyanide (Abeye, 1998). Also, it has been reported that consumption of food substances containing hydrogen cyanide may cause death within few hours (Fina, 2004). This is however dependent on the amount consumed in the food material. Most importantly, the recommended safe (tolerable) limit of cyanide for human consumption is $10 \mathrm{mg} \cdot \mathrm{kg}^{-1}$ (Coursey, 1983). Therefore, this studies 
report the levels of $\mathrm{HCN}$ in cassava, cocoyam, aerial yam, and trifoliate yam tubers obtained from Gboko local Government area of Benue State, Nigeria, hence these food materials form a staple diet among the people of this area.

\section{Materials and Methods}

The tubers of cassava, aerial yam and trifoliate yam were collected from Gboko local Government area in Benue state. The samples were identified by a Botanist of the biological science department, Benue State University, Makurdi. The peels were removed and the inner parts of the samples were sun-dried to a constant weight. The dried samples were ground, then sieved to fine particles, while the fresh samples were also ground to fine particles for analysis.

\section{Hydrogen Cyanide Determination}

Alkaline titration procedure was adopted (Anhwange, 2004). Ten grams of each of the ground samples were soaked in the mixture of $200 \mathrm{~cm}^{3}$ of distilled water and $10 \mathrm{~cm}^{3}$ of orthophosphoric acid. The mixture was kept for 12 hours to release all the bonded cyanide. The mixture was then distilled until $150 \mathrm{~cm}^{3}$ of the distillate was collected. $20 \mathrm{~cm}^{3}$ of the distillate was taken into a conical flask containing $40 \mathrm{~cm}^{3}$ of distilled water, $8 \mathrm{~cm}^{3}$ of ammonia solution $\left(6 \mathrm{mold} \cdot \mathrm{m}^{-3}\right)$ and $2 \mathrm{~cm}^{3}$ of potassium iodide $(5 \%)$ solution were added. The mixture was titrated with silver nitrate $\left(0.02 \mathrm{mold} \cdot \mathrm{m}^{-3}\right)$ to faint but permanent turbidity $\left(1 \mathrm{~cm}^{3} 0.02 \mathrm{mold} \cdot \mathrm{m}^{-3} \mathrm{AgNO}_{3} \equiv 1.08\right.$ $\mathrm{mg} \mathrm{HCN})$. Replicates determination were done for each of the samples.

\section{Statistical Analysis}

Means of the fresh and dried samples were compared using student t-test and the level of significant difference determined at $\mathrm{p}<0.05$ (Parker, 1979).

\section{Results and Discussion}

Result of the assessment of cyanide $\left(\mathrm{mg} \cdot 100 \mathrm{~g}^{-1}\right)$ in Cassava, Cocoyam, Aerial yam, and Trifoliate yam both fresh and dried tubers are presented as follows:

From the result, the content of hydrogen cyanide; $\mathrm{mg} \cdot 100 \mathrm{~g}^{-1}$, in fresh Cassava, Cocoyam, Aeriel yam, and Trifoliate yam tubers were $304.60,34.10,49.70$, and 79.40 respectively. The cyanide content of the dried samples was found to be $249.50 \mathrm{mg} \cdot 100 \mathrm{~g}^{-1}$, for Manihort utilissima, $17.3 \mathrm{mg} \cdot 100 \mathrm{~g}^{-1}$, for Colocasia esculenta, $32.4 \mathrm{mg} \cdot 100 \mathrm{~g}^{-1}$, for Dioscorea bulbifera and $55.1 \mathrm{mg} \cdot 100 \mathrm{~g}^{-1}$ for Dioscorea domentorum. Generally the cyanide content was higher in the fresh tubers than the dried tubers.

The amount of hydrogen cyanide was found to be highest in cassava tuber for both the fresh and dried samples; $304.60 \mathrm{mg} \cdot 100 \mathrm{~g}^{-1}$ and $249.50 \mathrm{mg} \cdot 100 \mathrm{~g}^{-1}$ respectively. Conversely, least levels of cyanide were obtained, in cocoyam tubers, $34.10 \mathrm{mg} \cdot 100 \mathrm{~g}^{-1}$ (fresh) and $17.30 \mathrm{mg} \cdot 100 \mathrm{~g}^{-1}$ (dried). In nutshell, the result showed that the order of the amounts of hydrogen cyanide $\left(\mathrm{mg} \cdot 100 \mathrm{~g}^{-1}\right)$ in the tubers was Colocasia esculenta $<$ Dioscorea bulbifera $<$ Dioscorea domentorum $<$ Manihort utilissima. Abaye et al. (1998), reports a high concentrations of cyanide $\left(86 \mathrm{mg} \cdot \mathrm{kg}^{-1}\right)$ in fresh cassava tubers, while the amounts for the dried sample is low $\left(15.70 \mathrm{mg} \cdot \mathrm{kg}^{-1}\right)$. The levels of $\mathrm{HCN}$ in cassava are largely due to environmental factors and duration of the drying. The normal range of cyanide content in cassava tubers is $15-400 \mathrm{mg} \cdot 100 \mathrm{~g}^{-1}$ (Anhwange, 2004).

According to Makkar et al. (1998), the FAO/WHO recommended safe limit of cyanide for human consumption is $10 \mathrm{mg} \cdot 100 \mathrm{~g}^{-1}$. Furthermore, the lethal dose of $\mathrm{CN}^{-}$was found to be between $50-250 \mathrm{mg} \cdot 100 \mathrm{~g}^{-1}$ for seeds (Ekandem et al., 2002).

Statistical analysis of the means of fresh and dried samples indicate that there was significant difference (at $\mathrm{p}<$ 0.05 ) between the fresh and the dried samples for all the tubers studied.

\section{Conclusion}

The literature values of cyanide contents of aerial yam, cocoyam, and trifoliate yam were not found. Although the analysis indicated that the tubers of these crops also contained this antinutritional factor (cyanide). Relatively, the amount of cyanide obtained from aerial yam, cocoyam, and trifoliate yam tubers were lower compared to that of cassava tubers in both fresh and dried samples.

Results of this study are in agreement with earlier works as it is being pointed out. Therefore, further antinutritional and chemical analysis should be done on these tubers, especially aerial yam, cocoyam, and trifoliate yam. Food crops found to contain high level of cyanide should be efficiently processed before consumption. 


\section{References}

Abaye, C.U., \& kelbessa, S.G. (1998). Health effect of cassava consumption in south Ethiopia. ast African Edition Journal, 75, 166-170.

Anhwange B.A, Ajibola, V.O, \& Oniye, S.J. (2004). Chemical Studies of the Seeds of Moringa oleifera, (Lam), and Detarium microcarpum (Guill, and Sperr). Journal Biological Science, 4(6), 711-715. http://dx.doi.org/10.3923/jbs.2004.711.715

ATSDTR. (1993). Agency for toxic substances and disease registry, Toxicological profile for cyanide, U.S dept. of Health and Human Services. public health service, $\mathrm{T}_{\mathrm{P}}-92 / 09$.

Coursey, D.G. (1983). Yams. Handbook of Tropical Foods (Chan, Hc (Jr) ed.). New York: 555-601.

Ekandem, I.E., Olonade, O.I., Chigbu, I.O., Orkater, N.D., \& Ibrahim, Q.O. (2002). Journal Chemical Society of Nigeria, 27(2), 109.

Jantz, E.R., \& Uluwaduge, D.I. (1997). Biochemical aspect of cassava (manihot esculenta crantz) with special emphasis on cyanogenic glucoside-A review. J Natural sciences, 25, 1-24.

Kamalu, B.P. (1995). The adverse effects of long term cassava (manihot esculenta crantz) consumption. Int. J. Food sci. Nutr., 46(1), 63-93. http://dx.doi.org/10.3109/09637489509003387

Makkar, H.P., Beckar, K. (1998). Plants toxins and detoxification methods to improve feed quality of tropical seeds. Asian-Australian Journal of animal science, 12, 467-480.

Parker R.E. (1979). Introductory Statistics for Biology. 2nd ed. Arnold publisher Ltd. London, 18-30.

Table 1 . Hydrogen cyanide contents $\left(\mathrm{mg} \cdot 100 \mathrm{~g}^{-1}\right)$ of cassava, cocoyam, and aerial yam, trifoliate yam tubers (fresh and dried samples)

\begin{tabular}{|c|c|c|}
\hline Samples & Fresh & Dried \\
\hline Manihort utilissima & $304.60 \pm 0.00 \mathrm{a}$ & $249.50 \pm 0.11 \mathrm{~b}$ \\
\hline Colocasia esculenta & $34.10 \pm 0.06 \mathrm{a}$ & $17.30 \pm 0.00 \mathrm{~b}$ \\
\hline Dioscorea bulbifera & $49.70 \pm 0.00 \mathrm{a}$ & $32.40 \pm 0.00 \mathrm{~b}$ \\
\hline Dioscorea domentorum & $79.40 \pm 0.06 \mathrm{a}$ & $55.10 \pm 0.00 \mathrm{~b}$ \\
\hline
\end{tabular}

Values followed with different alphabets are significantly different. 